\title{
PEMANFAATAN KULIT UBI KAYU SEBAGAI BIOSORBEN PADA PENJERNIHAN AIR DI KELURAHAN BALAROA
}

\author{
[Utilizing of Cassava Peel as Biosorbent for Water Purification in Balaroa] \\ Syaiful Bahri ${ }^{{ }^{\star}}$, Musafira ${ }^{1}$, Jaya Hardi $^{1}$, Pasjan Satrimafitrah $^{1}$ \\ 1 Jurusan Kimia Fakultas MIPA, Universitas Tadulako \\ Jl. Soekarno Hatta Km.9, Kampus Bumi Tadulako Tondo Palu, Telp. 0451- 422611
}

Diterima 31 Juli 2017, Disetujui 10 Agustus 2017

\begin{abstract}
The investigation about the adsoption of Fe ion came from the well water on cassava peel biosorbent has been done. The aim of the study is to determine the effect of cassava peel biosorbent on the amount of $\mathrm{Fe}$ ions by modification tools. Well waters was obtained from Balaroa area, Palu City, Indonesia. Biosorbent of cassava peel was combined by charcoal and gravel that is placed on the tools. The result showed that well water from filtering more clear than before filtering. The well water filtered was not resulted sediment of iron after storage for two weeks.
\end{abstract}

Keywords : Fe ion, biosorbent, cassava peel, well water.

\begin{abstract}
ABSTRAK
Kajian mengenai penjerapan ion logam Fe dalam air tanah menggunakan biosorben kulit ubi kayu telah berhasil dilakukan. Tujuan dari kajian ini adalah untuk menentukan pengaruh biosorben kulit ubi kayu terhadap sejumlah ion Fe dengan modifikasi perangkat alat penjernihan. Air tanah diperoleh dari Kelurahan Balaroa, Kota Palu, Indonesia. Biosorben kulit ubi kayu dikombinasikan dengan arang dan kerikil dalam perangkat alat penjernihan. Hasil kajian menunjukkan bahwa air tanah hasil penyaringan lebih jernih dibandingkan sebelum perlakuan. Air tanah hasil penyaringan tidak menghasilkan endapan besi setelah penyimpanan selama dua minggu.
\end{abstract}

Kata kunci: ion Fe, biosorben, kulit ubi kayu, air tanah 


\section{LATAR BELAKANG}

Kualitas air membutuhkan perhatian lebih sebagai kebutuhan manusia yang sangat penting. Pada saat ini, ketersediaan air sesuai dengan kualitas yang dimaksudkan sangat sulit didapatkan. Masalah tersebut muncul karena kebanyakan pencemaran air diakibatkan oleh kegiatan industri, limbah rumah tangga, dan lainnya. Selain itu, berbagai daerah, sumber air minumnya berasal dari air yang berwarna keruh dan kekuningan yang kadar Fe yang cukup tinggi sehingga tidak bisa langsung dikonsumsi. Khususnya di Kelurahan Balaroa, Kecamatan Palu Barat, Kota Palu, warga setempat mengeluhkan kondisi air yang berwarna dan keruh. Kondisi tersebut mengindikasikan kandungan ion Fe yang tinggi pada air warga. Dilain pihak kandungan $\mathrm{Fe}$ yang tinggi dapat menyebabkan beberapa penyakit, seperti mual dan muntah, sirosis hati, gatal-gatal, hipertensi, dan lainnya. Dalam rangkan mengatasi hal tersebut, perlu dilakukan dengan pengolahan air untuk mengurangi kadar $\mathrm{Fe}$ yang terkandung di dalamnya (Wardana, 2004).

Pencemaran ion logam berat dalam air telah banyak ditangani untuk mengatasi resiko keracunan bagi makhluk hidup. Salah satu teknik yang umum digunakan adalah teknik adsorpsi menggunakan bahan organik ataupun lebih dikenal sebagai biosorben. Teknik ini sangat menguntungkan karena biaya yang diperlukan tidak begitu besar serta tidak adanya efek samping (Ingole \& Dharpal, 2012).

Salah satu produk alam yang juga memiliki potensi untuk menyerap logam yaitu kulit ubi kayu. Limbah ini dapat dimanfaatkan untuk menanggulangi pencemaran logam berat yaitu sebagai biosorben karena adanya kandungan selulosa yang cukup tinggi sebesar 43, $63 \%$. Adanya kandungan selulosa tersebut merupakan potensi yang besar untuk digunakan sebagai biosorben (Suhendaryatna, 2001).

Berdasarkan penelitian Laroni (2014) mengenai pemanfaatan limbah kulit singkong untuk menyerap ion Fe dengan metode batch (pengocokan), hasil tertinggi pada waktu kontak 80 menit dengan persentase penyerapan sebesar $63,78 \%$ dan pada rasio $0,4: 10 \mathrm{mg} / \mathrm{ml}$ dengan persentase penyerapan sebesar $65,20 \%$. Dari hasil penelitian yang telah dilakukan, menunjukan bahwa kulit ubi memiliki potensi untuk menyerap logam Fe (Laroni, 2014).

\section{METODE PENELITIAN}

\section{Bahan dan Peralatan}

Bahan yang digunakan diantaranya kulit ubi kayu, natrium hipoklorit, aquades, air sumur warga kelurahan Balaroa.

Peralatan yang digunakan adalah blender, ayakan 20 mesh, rangkaian alat penyaringan, neraca analitik, Spektrofotometri UV-Vis, dan alat-alat gelas yang umum digunakan dalam laboratorium kimia, aluminium foil. 


\section{Prosedur Penelitian}

\section{Preparasi Kulit Ubi Kayu (Modifikasi Metode Laroni, 2014)}

Kulit ubi kayu yang sudah dipisahkan dari kulit luarnya dicuci dengan air bersih.

Setelah itu direndam dengan air hangat \pm 5 menit. Dijemur dibawah terik matahari hingga kering \pm 5 hari, kemudian dihancurkan lalu diayak dengan ayakan 20 mesh. Kulit ubi kayu selanjutnya dicuci dan direndam dengan natrium hipoklorit $2 \%$ yang diulangi selama $2 \times 24$ jam, kemudian dicuci dengan air. Kulit ubi kayu yang sudah kering siap digunakan sebagai biosorben.

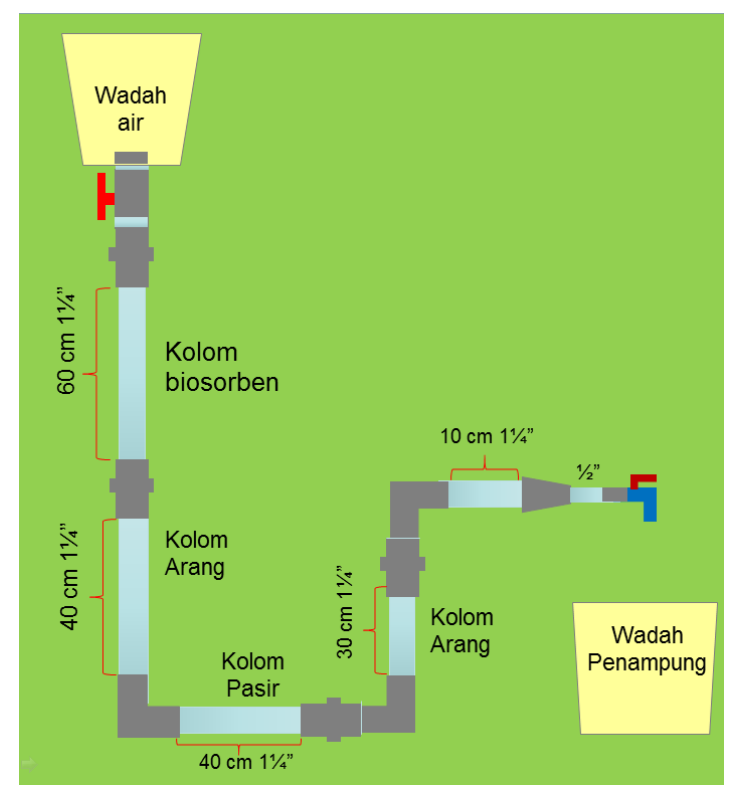

Gambar 1 Rangakain alat penjernihan air

Penjernihan Air dengan Biosorben Ubi Kayu (Modifikasi Metode Tepare, 2017])

Pada pipa rangkaian yang sudah dirangkai seperti pada Gambar 1, dimasukkan sampel pada wadah/ember. Sampel dialirkan melalui pipa sebagai kolom dengan diameter $1 \frac{11 / 4}{4}$ inchi dan panjang biosorben $60 \mathrm{~cm}$. Pada bagian lain ditempatkan arang dan kerikil. Hasil dari sampel yang dialirkan melalui pipa dan ditampung kemudian dianalisis penampakan fisik dari air hasil penjernihan. Hasil penjernihan juga didiamkan selama dua minggu dan selanjutnya dibandingkan dengan air sebelum penjernihan.

\section{HASIL DAN PEMBAHASAN}

Proses penjernihan air sumur di daerah kelurahan Balaroa dilakukan dengan menggunakan raingkaian alat sederhana menggunakan biosorben selulosa dari kulit ubi kayu. Kulit ubi kayu yang digunakan terlebih dahulu dicuci dengan natrium hipoklorit untuk menghilangkan zat warna di dalam kulit ubi kayu. Air sumur yang digunakan adalah air sumur warga setempat yang berwarna kuning dan keruh. Penyaringan air dilakukan langsung dilokasi pengambilan sampel (Gambar 2), yaitu RW 9 Kelurahan Balaroa, Kecamatan Palu Barat, Sulawesi Tengah. Hal tersebut dilakukan guna mengenalkan teknologi sederhana langsung kepada masyarakat.

Hasil penjernihan yang dilakukan menunjukkan hasil yang lebih jernih dibandingkan sebelum penyaringan. Hal tersebut mengindikasikan bahwa ion $\mathrm{Fe}$ dalam air telah diserap oleh biosorben kulit ubi kayu. Ion Fe terjerap di dalam serat selulosa yang terdapat di kulit ubi kayu.

Pada proses adsorpsi ini, melibatkan reaksi kimia antara selulosa dan ion logam $\mathrm{Fe}$ yang terdapat dalam air. Selulosa 
mempunyai kemampuan untuk mengadsorpsi logam berat. Hal ini dikarenakan selulosa memiliki gugus hidroksil yang dapat berinteraksi dengan logam berat. Menurut Nurhayati dan Sutrisno, bahan-bahan yang mempunyai gugus hidroksil $(-\mathrm{OH})$ dapat dipakai untuk mengadsorpsi ion-ion logam berat (Nurhayati \& Sutrisno, 2013).

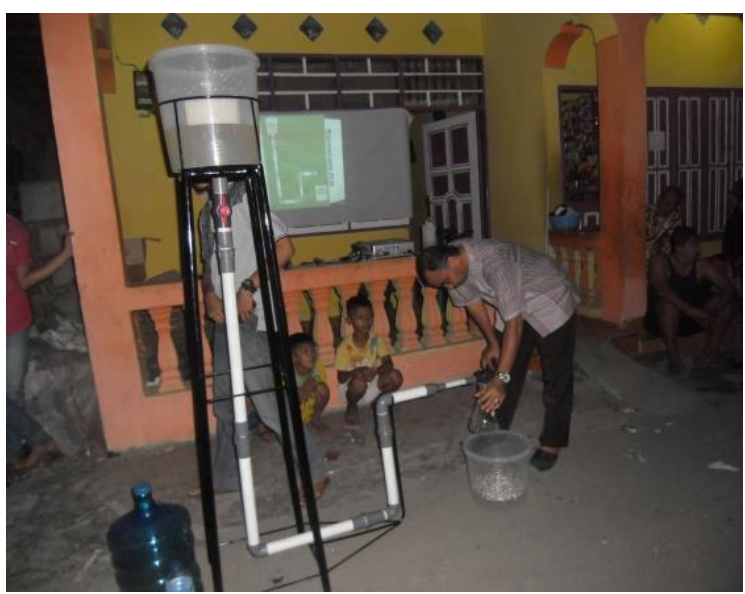

Gambar 2. Proses penjernihan air

Hasil penjernihan didiamkan selama dua minggu untuk melihat apakah terjadi pengendapan logam besi atau tidak. Berdasarkan hasil yang diperoleh, air hasil penyaringan dengan biosorben tidak menghasilkan endapan sedangkan air sebelum penyaringan menghasilkan endapan berwarna merah bata pada bagian bawah wadah (Gambar 3). Endapan tersebut merupakan logam besi yang mengendap dan masih terkandung di dalam air tanah atau sampel. Hasil tersebut menunjukkan bahwa teknik penjernihan yang dilakukan telah berhasil mereduksi ion besi dalam air tanah warga RW 9 Kelurahan Balaroa, Kota Palu.

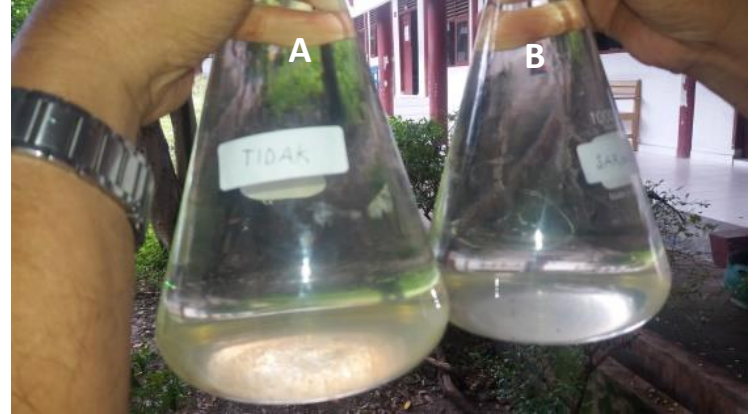

Gambar 3. Perbandingan air sebelum (A) dan setelah penyaringan (B)

\section{KESIMPULAN}

Berdasarkan hasil yang diperoleh dapat disimpulkan bahwa biosorben kulit ubi sangat efektif menurunkan kadar ion Fe dalam air tanah.

\section{UCAPAN TERIMAKASIH}

Ucapan terimakasih penulis haturkan kepada pihak DRPM Kemenristek Dikti yang telah memberikan bantuan dana pengabdian.

\section{DAFTAR PUSTAKA}

Ingole Nitin W., Dharpal Sachin V. 2012. State of Art of Biosorption Technique for Treatment of Heavy Metals Bearing Wastes. International Journal of Advanced Engineering Technology. 3(2): 143-153.

Laroni J.I. 2014. Pemanfaatan Kulit Ubi Kayu (Manihot utillissima Pohl) Sebagai Biosorben Logam Fe. Skripsi. Palu: Jurusan Kimia FMIPA Universitas Tadulako.

Nurhayati I, Sutrisno J. 2013. Limbah Ampas Tebu Sebagai Penyerap Logam Berat $\mathrm{Pb}$. Prosiding.Seminar Nasional Universitas PGRI Adi Buana Surabaya. Hal: 59-70.

Suhendaryatna. 2001. Bioremoval Logam Berat dengan Menggunakan Mikroorganisme:Suatu kajian Kepustakaan.(http://www.google.com /biosorpsi logam berat). Diakses tanggal 24 februari 2016. 
Tepare E. 2017. Aplikasi Biosorben Kulit Ubi Kayu (Manihot utillissima Pohl) dalam Penyerapan Ion Fe(lii) Pada Air Payau. Skripsi. Palu: Jurusan Kimia FMIPA Untad.

Wardhana W. 2004. Dampak Pencemaran Lingkungan. Yogyakarta: ANDI. 